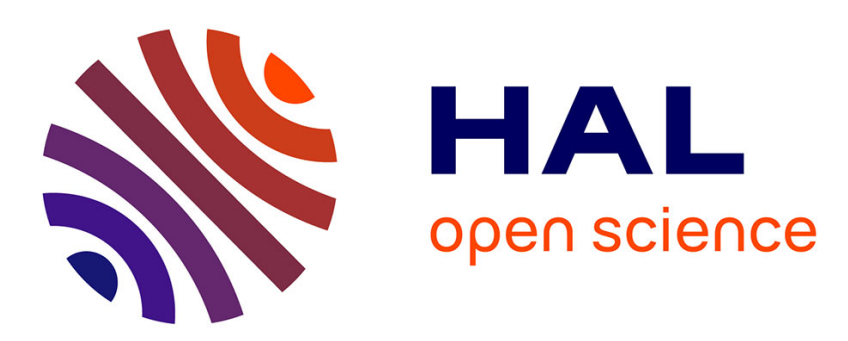

\title{
Legal Mobilization within the Bureaucracy. Disability Rights and the Implementation of Antidiscrimination Law in Sweden
}

Aude Lejeune

\section{- To cite this version:}

Aude Lejeune. Legal Mobilization within the Bureaucracy. Disability Rights and the Implementation of Antidiscrimination Law in Sweden. Law and Policy, 2017, 39 (3), pp.237-258. 10.1111/lapo.12077 . hal-02388943v2

\section{HAL Id: hal-02388943 \\ https://hal.univ-lille.fr/hal-02388943v2}

Submitted on 8 Jan 2020

HAL is a multi-disciplinary open access archive for the deposit and dissemination of scientific research documents, whether they are published or not. The documents may come from teaching and research institutions in France or abroad, or from public or private research centers.
L'archive ouverte pluridisciplinaire HAL, est destinée au dépôt et à la diffusion de documents scientifiques de niveau recherche, publiés ou non, émanant des établissements d'enseignement et de recherche français ou étrangers, des laboratoires publics ou privés. 
Lejeune, Aude. 2017. Legal Mobilization within the Bureaucracy: Disability Rights and the Implementation of Antidiscrimination Law in Sweden, Law \& Policy, 39(3), 237-258, https://doi.org/10.1111/lapo.12077.

\title{
Legal Mobilization Within the Bureaucracy: \\ Disability Rights and the Implementation of Antidiscrimination Law in Sweden
}

\author{
Aude Lejeune, CNRS Faculty Research Fellow
}

This paper argues that the analysis of legal mobilization needs to give more attention to the state and its relationship with social movements in order to examine how the state either sustains social movements' demands or is a field of contention for those demands. Focusing on how disability bureaucrats and activists mobilize antidiscrimination law in Sweden, this article shows that two main factors shape legal mobilization within the bureaucracy and alter the state's ability to become a legal mobilization actor: (1) the institutional relationships between social movement organizations and government agencies; and (2) the profiles and careers of bureaucrats and activists. It concludes by suggesting several lines for further research on law and social movements in nonpluralist countries.

Keywords: Actors' Agency; Disability; Discrimination; Law Enforcement; Legal Mobilization; NGOs; Ombudsman; Politics of Rights; Social Movements; State; Street-level Bureaucracy; Strategic Litigation; Sweden.

\section{INTRODUCTION}

For more than four decades, sociolegal scholars have analyzed the mobilization of the law by social movements. Research has emphasized not only how legal strategies can contribute to producing social change but also how legal discourse frames social movements' claims. This paper argues that, in the analysis of legal mobilization, more attention needs to be given to the role of the state and its relationship with social movements in order to examine how the state can be a site of legal mobilization and how, in such cases, it either supports social movements' demands or is a field of contention for those demands. In order to explore the relationship between law, social movements, and the state, as well as the role of the state as a legal mobilization actor, this article focuses on how disability activists and bureaucrats of the Discrimination Ombudsman in Sweden mobilize antidiscrimination law to promote the inclusion and full participation of disabled people in the labor market.

This article addresses two main research questions. First, how do the institutional relationships between state agencies and social movement organizations, which change over time, influence or alter the ability of the bureaucracy to become a legal mobilization 
actor? Second, how do the profiles and careers of bureaucrats and activists, especially those who have moved from non-government to government organizations, shape their everyday work with the law and influence the provision of government services?

To answer these questions, this article suggests bringing the state back into the law and social movement literature (I). It also explains the case selection procedure and the relevance of examining legal mobilization in a neocorporatist country, and sets out the methodology and data collection technique used (II). It then recounts the history of Swedish disability policy over the past twenty years from a diachronic perspective, examining how the government agency that has been in charge of antidiscrimination and equal opportunity during this period has cooperated or clashed with the disability movement and how these historical changes in the relationship between bureaucrats and disability activists have shaped the agency's legal strategies (III). The article then discusses the role of the bureaucracy in legal mobilization. It argues that there are two main factors at play: first, the institutional relationships that the government agency establishes with civil society organizations and, second, the networks and identities of the bureaucrats (IV). It concludes by suggesting several lines for further research on law and social movements in nonpluralist countries ${ }^{1}$.

\section{THEORETICAL FRAMEWORK: LAW, SOCIAL MOVEMENTS, AND THE STATE}

I will briefly present the literature on law and social movements and explain the benefit of bringing the state back into the analysis of legal mobilization (1). I will then suggest adopting a broad definition of legal mobilization that includes recourse to legal strategies outside the courtroom and pays attention to one specific stage of policymaking, when bureaucrats put the policy into action and implement the law (2).

\section{Bringing the state back in}

For more than four decades, sociolegal scholars have analyzed the mobilization of the law by social movements (Barnes and Burke 2012; Barclay, Jones, and Marshall 2011; Vanhala 2011; Zeman 1983; Black 1973). Research has emphasized how legal strategies can be social movement tactics (Burstein 1991) and can contribute to producing social change (Israël 2009; Scheingold 2004 [1974]). Studies have also shown how legal discourse produces cultural meaning (Ewick and Silbey 1998) and thus frames social movements' claims (McCann 1994, 2006; Marshall 2003).

From this perspective, sociolegal scholars have examined the structural and cultural factors that influence recourse to legal strategies. They have developed the concept of legal opportunity structure, which stipulates that various criteria-such as available legal resources, legal stock, or the receptiveness of judges-determine the choice to litigate (Andersen 2006; Epp 1998). Other scholars have shown that these structural explanations are not enough to understand how and why activists and lawyers decide to mobilize the law and take legal action (Cichowski 2013; Hilson 2002). They have

\footnotetext{
${ }^{1}$ Previous versions of this paper were presented at the Council for European Studies Conference in 2015 in a workshop on "Legal Mobilization in Europe" and at the Disability Conference "2005-2015: Quel anniversaire pour les personnes handicapées?" organized by Pierre-Yves Baudot and Yohann Aucante. I gratefully acknowledge the participants, Anne Revillard and Anna-Maria Marshall, for their useful comments on earlier drafts. I am also grateful to the researchers of the SCORE center at the University of Stockholm for our discussions and to the University of Lille for financial support.
} 
suggested that sociolegal studies should pay closer attention to the agency of lawyers and activists rather than focus solely on structural factors (Vanhala 2012; Sarat and Scheingold 2005). According to these scholars, by mobilizing the law, lawyers and activists translate people's experiences into legal categories (Bumiller 1987), make a cause visible to the public (Sarat and Scheingold 2006), empower marginalized groups (Engel and Munger 2003), or reinforce a movement's collective identity (Vanhala 2011; Polletta and Jasper 2001). In short, these works suggest that one should take into account the diversity of lawyers' and activists' profiles and careers, their professional and personal commitments, and the meanings they attach to legal mobilization. They have shown that, in the same context and with the same resources, lawyers and activists have different options, and their decisions and choices influence how and why they mobilize the law.

These works on law and social movements cover a wide variety of practices in different social and political contexts. However, one dimension remains underexamined by the existing literature: how bureaucracy mobilizes the law to conceptualize, to balance, and to realize policy, and how its relationships with social movements shape the bureaucrats' legal strategies. When legal mobilization literature has examined the state's connections and relationships with social movements, it has mostly focused on the activities of private groups. It has demonstrated that the relationships these groups have with state actors shape these private groups' willingness to mobilize the law and the courts. Some of these works have compared different national jurisdictions and have analyzed the state as a structural variable of the context that determines the ability of civil society groups to mobilize the law and the courts. Several recent studies have qualified this assessment by suggesting that legal mobilization varies across different civil society groups within the same institutional context (Vanhala 2016; Soennecken 2013; Morag-Levine 2003). All of these works share one common characteristic: they analyze the legal activities of civil society actors that challenge either the state or government agencies but they give little attention to the actors who file lawsuits and appeal to the law to produce social change from within state institutions. This paper proposes to look at the other side of the relationship and examine how state actors mobilize the law to achieve political and social aims. From this perspective, a bureaucracy can also function as a legal mobilization arena because a certain agency or actor within the state can challenge a certain policy supported by another part of the state.

In the literature on social movements and protests that does not specifically deal with law and legal strategies, several scholars have emphasized the blurred boundaries between the state and social movements (Johnston 2010). They have suggested that institutions can be the site of political and social struggles and that protest should not be seen as something that can only take place outside of institutions (Bereni and Revillard 2012; McBride and Mazur 2010; Banaszak 2009; Katzenstein 1998). Aside from this literature, which encourages us to think of the relationship between social movements and the state as a continuum rather than as a relationship between two separate entities, sociolegal scholars have paid little attention to the role of the state and the bureaucracy as actors in legal mobilization and rights mobilization ${ }^{2}$.

\footnotetext{
${ }^{2}$ Several studies analyze federal government agencies as arenas in which individual plaintiffs file complaints. However, these works do not specifically examine the role of the bureaucracy as a legal mobilization actor (Burstein 1991; Hirsh and Kornich 2008).
} 
Several works are exceptions that invite us to further explore the role of state institutions and actors in the process of legal mobilization. These works have addressed this question from three different but interconnected perspectives. First, some scholarship has focused on the role of bureaucracy in the politics of rights. Nicholas Pedriana and Robin Stryker (2004) have argued that the mobilization of the law by disadvantaged groups has contributed to extending the state's ability to enforce the law and achieve policy goals. From the same perspective, Pierre-Yves Baudot and Anne Revillard $(2014,2015)$ have examined how the state contributes to the promotion of rights through the definition and implementation of public policies and how, in their everyday practices, civil servants make citizens' rights a reality. Second, some studies have given attention to the development of partnerships between bureaucrats and social movement activists. In his study on how legal liability is used by activists and bureaucrats, Charles Epp (2009) found that reform-oriented managers working within state agencies develop partnerships with lawyers and activists. Through this process, court-led reforms directly affect bureaucracies because managers integrate legalized accountability into bureaucratic practices. Finally, some research has challenged the idea of a clear boundary between government lawyers and cause lawyers and has shown that lawyers can promote social change from within the state (Berenson 2009; NeJaime 2012). From this perspective, a recent study by Paul Nolette (2015) argues that, in addition to private actors, government prosecutors can also mobilize the law to produce social and policy change when they lead litigation campaigns. According to Nolette, not all of the legal activities of bureaucrats constitute legal mobilization. To be considered as such, they need to present three characteristics: their litigation "ha[s] the direct effect of forcing organizational change," "their campaign (also serves) as a vehicle to expand the scope of the conflict," and finally, "this government-led litigation has [...] the constitutive effect of establishing new legal norms transforming existing understandings of key concepts" (Nolette 2015, 126). Continuing the line of research established by these works, this paper suggests looking at the institutions of the state to understand how bureaucrats mobilize the law and how they follow, reinforce, or oppose social movements' legal strategies. It looks at the exchanges, interactions, and transfers between the bureaucrats of state institutions and the activists taking part in social movements. It also examines how legal strategies are organized, planned, and implemented through the interconnections between the state and social movements' organizations.

This paper also bridges studies on legal mobilization and literature on street-level bureaucracy (Lipsky 2010 [1980]). It examines the activity of public servants who work for government institutions that enforce the law and implement public policy. In Michael Lipsky's work, he points out that there is variation among street-level bureaucrats in the extent to which they enforce the rules and laws assigned to them. In this paper, I argue that bureaucrats working within state institutions have the opportunity to influence the services delivered by the government and that their choices influence how and why legal mobilization occurs. But this paper also shows that these bureaucrats' "substantial discretion in the execution of their work" and their relationship with the public-which are the main characteristics of street-level bureaucrats (Lipsky 2010 [1980], 3)—may vary over time due to institutional reforms. 


\section{Legal mobilization and litigation at the stage of policy implementation}

Legal strategies can be very diverse. They can occur at different stages of the policy making process: when stakeholders raise concern about some problems, when the problem is discussed within various arenas, when executives put the policy into action and implement the policy, etc. At the stage of policy implementation, the literature has mostly focused on mobilization of the courts and how NGOs and advocacy groups use litigation to produce policy change and social change (Vanhala, 2009; Epp, 1998; McCann, 1994). In these works, legal mobilization concerns litigation only in the sense of "the process by which individuals make claims about their legal rights and pursue lawsuits to defend or develop those rights" (Epp 1998). This definition of legal mobilization as being equivalent to litigation partly stems from the fact that this body of literature originates in the United States (Revillard 2016; Soennecken 2013). The vast majority of research has used the US as a case study and examined one particular type of legal mobilization: the struggle for equal opportunity, and more particularly the mobilization of legal strategies by social movements and minorities. In this specific context, the "civil rights template" has been prevalent as "a public policy model in which social injustices are addressed through lawsuits that aim to punish individual acts of discrimination" (Burke 2015). According to Paul Burstein (1991, 1204), "it is, in fact, impossible to understand the American struggle for equal opportunity without focusing on the courts and on activities intented to influence judicial decisions [...] In Tilly's language, litigation has been an important part of the repertoire of those seeking equal opportunity, at least since the NAACP began its campaign against segregation during the 1930s."

Some scholars, even in the United States, have mentioned the need to adopt a broader definition of legal mobilization because "courts are not the only arenas in which activists invoke rights claims and attempt to give them legal force" (Southworth 2000, 1208). They suggest taking into account the various processes through which individuals or collective actors "invoke legal norms, discourse, or symbols to influence policy or behavior" (Revillard 2016; Vanhala 2011; Zeman 1983; Black 1973) or to challenge a violation of their rights (Lejeune and Orianne 2014; Fuller, Edelman, and Matusik 2000; Felstiner, Abel, and Sarat 1981). A broader definition of legal mobilization seems useful for understanding how the law can be a tool for collective mobilization and how it frames social protests. From this perspective, litigation is one of a broad range of legal strategies that social movements, activists, lawyers, and bureaucrats employ to make rights claims. ${ }^{3}$ As this study analyzes the legal activity of bureaucrats at the policyimplementation stage, it will examine the legal strategies they employ to enforce the law when the law has already been passed and implemented rather than strategies to change existing legislation.

\section{METHOD: HOW TO STUDY LEGAL MOBILIZATION?}

To study legal mobilization within the bureaucracy and the relationship between law, social movements, and the state, this article focuses on the struggle for the inclusion and full participation of people with disabilities in Sweden's labor market. I will explain this choice (1) and then describe the data collection and method (2).

\footnotetext{
${ }^{3}$ Legal strategies can also be combined with other non-legal strategies, such as the use of the media.
} 


\section{Case selection: Swedish disability rights policy and access to the labor market}

Swedish disability rights policy provides a promising vantage point from which to study the relationships between law, social movements, and the state as well as their implications with regard to legal mobilization. It is worth highlighting three of the main reasons for this. First, historically, the roots of Swedish disability policy are to be found in the establishment of the welfare state, which collaborated closely with organizations from civil society. This history still influences the nonprofit sector's heavy involvement in disability policy today. Sweden is generally considered a neo-corporatist system (Lindvall and Sebring 2005; Rothstein 1988), which "values [...] cooperation between state organizations and peak civil society organizations and where consensus decision making and civil society involvement in policy implementation are the norms" (Vanhala 2016, 104). In this context, the thirty-nine disability organizations making up the Swedish Disability Federation receive financial support from the state and play a major role in defining and implementing the country's disability policy (Hugemarka and Roman 2007). ${ }^{4}$ In terms of legal mobilization behavior, we might expect the relationships between state actors and civil society organizations to be more important in neo-corporatist states, where consensus decision-making and compromise between the state and corporatist groups are favored over conflict (Soennecken 2013; MoragLevine 2003).

Second, as in many countries, disability policy in Sweden was primarily based on a social welfare model and on specific socioeconomic rights and provisions catering to the needs of people with disabilities who are considered unable to participate in society. The Discrimination Act, passed in 2009, is rather based on a rights model (Lindqvist 2000). According to this model, people with disabilities are no longer seen as physically and mentally impaired but rather as people who have the right to fight for inclusion in society. They become "active rights holders [...] and they should use the force of the law to protest their segregated status as a form of discrimination" (Heyer 2015, 26). This new legal framework opened up new opportunities to promote the rights of people with disabilities through litigation (Burke, 2004). Recent changes to disability policy in Sweden provide us with an opportunity to explore how the strategies of the disability movement have evolved over the last two decades since the first law prohibiting discrimination against people with disabilities was passed (1994-2014) as well as how lawyers and activists within and outside the state mobilize the antidiscrimination legal framework.

Third, the Discrimination Act also created a new government agency dedicated to fighting discrimination on the grounds of disability and other criteria. This agency, called the Discrimination Ombudsman, works in close collaboration with nonprofit disability organizations. Depending on the time period considered, the agency's relationship with NGOs has evolved and changed, moving from close collaboration to competition and conflict. Analysis of the role of this new public actor is relevant for understanding how its relationships with other organizations in the field shape how the law is mobilized to promote the inclusion and non-discrimination of disabled people within Swedish society.

To explore how legal mobilization is shaped by the relationship between the state and disability rights activists, I focus specifically on mobilization that promotes access to the labor market and employment for people with disabilities. The Swedish labor market

4 These organizations count among the members of the government's disability council. 
model, which is historically inclusive and based on the protection of workers at the collective level, is an interesting arena for exploring how legal mobilization occurs. Nondiscrimination and full participation in the labor market has become one of the main struggles of the country's disability rights movement. Unlike the social welfare approach, which specifically gives priority to socioeconomic compensation for people with disabilities, the approach taken by disability rights activists places the emphasis on the barriers that people with disabilities face when trying to access and retain employment. Although the philosophies of these two competing approaches to disability and inclusion (compensation vs. rights) are incompatible, many countries combine them in their disability policy, as Katharina Heyer (2015) has shown regarding Germany and Japan. In Sweden, the rights-based model promoted by the Discrimination Act created conflict among disability activists, labor unions, and the government. Some activists believed that the law was not ambitious enough to protect disabled workers from discrimination and that the rights model should have been put forward. Others believed that introducing antidiscrimination policy into an inclusive labor market model provided less protection for vulnerable and disabled workers, both because the antidiscrimination policy was based on individual rights rather than on measures that promote the integration of disabled workers into the labor market at the collective level (Michailakis 2000) and also because the antidiscrimination framework encouraged employers to reduce their discrimination liability instead of promoting a more inclusive workplace. ${ }^{5}$ Indeed, it relied on individuals' ability or desire to set the legal process in motion in order to gain financial, moral, and legal compensation (Lejeune 2013) while the disability movement's primary demand was based on broader accessibility and inclusion for people with disabilities at the collective level.

\section{Data collection and analysis}

The aim of this paper is to understand how lawyers, activists, and bureaucrats working for government agencies use legal strategies, how they either cooperate or do not cooperate with the disability rights movement to build their legal strategies, and what meanings they attach to legal mobilization. For this reason, the investigative techniques used primarily consist of open-ended interviews $(\mathrm{N}=24)$ with members of different nonprofit organizations and with staff from the Discrimination Ombudsman.

- Fourteen semistructured interviews were conducted at the Diskriminering Ombudsmannen in Stockholm with legal advisors, case officers, policy officers, and managers in charge of disability policy.

- Six interviews were conducted with lawyers and activists working in local nonprofit organizations supporting human rights and equal opportunity (Rättighetscenter) in four Swedish cities: Stockholm, Örebro, Uppsala, and Malmö.

- Four interviews were conducted with people working in two national nonprofit disability rights organizations: the Swedish Federation of Disabled Persons (DHR), an organization for people with impaired mobility, and the Swedish National Association for Persons with Intellectual Disability (FUB).

\footnotetext{
${ }^{5}$ Shauhin Talesh has made the same argument in his analysis of the role of insurance companies in constructing compliance with antidiscrimination law in the United States (Talesh 2015).
} 
During the interviews, lasting one to three hours, I asked them to speak about their professional careers, their commitment to the disability cause, their relationship and connections with the disability movement, their specific expertise and knowledge, and the meaning they attach to legal mobilization. But I also asked them to talk about their everyday work promoting disability rights, the legal strategies they use, the members of the public they meet, and how much room they have for autonomy in their day-to-day activities. The interviews specifically focused on their work on nondiscrimination norms in general and in relation to the Swedish Discrimination Act in particular. I then analyzed the interview transcripts to examine how lawyers, activists, and bureaucrats use legal strategies and give meaning to legal mobilization.

In addition to interviews, I searched archived annual reports and official documents produced by the Discrimination Ombudsman in order to get information about the history of the organization. I also draw on disability cases brought before the labor court by the Discrimination Ombudsman and by nonprofit organizations from 2005 to 2012 .

\section{ANALYSIS: THREE PHASES OF THE RELATIONSHIP BETWEEN THE DISABILITY MOVEMENT AND THE STATE}

In the recent history of disability policy in Sweden, three periods of cooperation and competition between the bureaucracy and nongovernmental organizations can be distinguished. Each period corresponds to the use of different legal strategies and mobilizations. In the first period, the state expanded its intervention, changing its role from welfare provision supplier to rights agency (1). In the second period, litigation became the main strategy for promoting access to the labor market for people with disabilities, and the NGOs were kept at distance (2). In the third period, the Discrimination Ombudsman expanded its legal strategies outside the courtroom, and its collaboration with NGOs was controversial (3).

\begin{tabular}{|c|c|c|c|}
\hline & $\begin{array}{l}\text { Phase } 1: \\
\text { The state, from } \\
\text { provision supplier to } \\
\text { rights-enforcement } \\
\text { agency } \\
(1994-2009)\end{array}$ & $\begin{array}{l}\text { Phase } 2: \\
\text { NGOs at a distance: } \\
\text { litigation and legal } \\
\text { professionalization } \\
(2009-2012)\end{array}$ & $\begin{array}{l}\text { Phase } 3: \\
\text { Various forms of } \\
\text { collaboration: fostering } \\
\text { compliance with the } \\
\text { law } \\
(2012-2014)\end{array}$ \\
\hline Agency & $\begin{array}{l}\text { Handicap Ombudsman } \\
\text { (HO). }\end{array}$ & $\begin{array}{l}\text { Discrimination } \\
\text { Ombudsman (DO). }\end{array}$ & $\begin{array}{l}\text { Discrimination } \\
\text { Ombudsman (DO). }\end{array}$ \\
\hline $\begin{array}{l}\text { Agency's main } \\
\text { goal in labor } \\
\text { issues }\end{array}$ & $\begin{array}{l}\text { To be recognized as a } \\
\text { rights-enforcement } \\
\text { agency. }\end{array}$ & $\begin{array}{l}\text { To extend its legitimacy } \\
\text { as a rights-enforcement } \\
\text { agency by means of } \\
\text { favorable decisions by } \\
\text { the labor court. }\end{array}$ & $\begin{array}{l}\text { To reinforce its } \\
\text { recognition as a neutral } \\
\text { and impartial } \\
\text { government agency. }\end{array}$ \\
\hline $\begin{array}{l}\text { Main legal } \\
\text { strategy }\end{array}$ & Various legal strategies. & $\begin{array}{l}\text { Litigation to produce } \\
\text { social change. }\end{array}$ & $\begin{array}{l}\text { Compliance with the law } \\
\text { among employers. }\end{array}$ \\
\hline $\begin{array}{l}\text { Recruitment } \\
\text { policy }\end{array}$ & $\begin{array}{l}\text { Grassroots activists, deep } \\
\text { connections with the }\end{array}$ & $\begin{array}{l}\text { Human rights lawyers, no } \\
\text { connection with the }\end{array}$ & No recruitment. \\
\hline
\end{tabular}




\begin{tabular}{|l|l|l|l|}
\hline $\begin{array}{l}\text { Agency-NGO } \\
\text { collaboration }\end{array}$ & $\begin{array}{l}\text { Sisability movement. } \\
\text { (HO) recruits many } \\
\text { grassroots disability } \\
\text { activists who work in } \\
\text { collaboration with NGOs. }\end{array}$ & $\begin{array}{l}\text { disability movement. } \\
\text { activists working for the } \\
\text { agency (DO) have few } \\
\text { disability movement; } \\
\text { collaboration and } \\
\text { competition on individual } \\
\text { cases. }\end{array}$ & $\begin{array}{l}\text { Variable since it depends } \\
\text { on the connections of the } \\
\text { bureaucrats who work } \\
\text { for the agency (DO). }\end{array}$ \\
\hline $\begin{array}{l}\text { Substantial } \\
\text { discretion in } \\
\text { the execution } \\
\text { of work }\end{array}$ & $\begin{array}{l}\text { Strong since various legal } \\
\text { strategies are possible. }\end{array}$ & $\begin{array}{l}\text { Strong since bureaucrats } \\
\text { have substantial } \\
\text { discretion in their } \\
\text { interaction with the } \\
\text { public (mostly citizens } \\
\text { who experience } \\
\text { discrimination). }\end{array}$ & $\begin{array}{l}\text { Weak since bureaucrats } \\
\text { have fewer opportunities } \\
\text { to define their strategy } \\
\text { through interaction with } \\
\text { the public (mostly private } \\
\text { companies and public } \\
\text { organizations). }\end{array}$ \\
\hline
\end{tabular}

Source: compiled by the author from interviews and research in the archives of the Discrimination Ombudsman's annual reports and official documents.

\section{The state, from provision supplier to rights-enforcement agency (1994-2009)}

Until the 1990s, the state mostly played the role of a provision supplier for people with disabilities. As in other Scandinavian social-democratic models based on universalistic social protection and an inclusive labor market (Etherington and Ingold 2012; Waldschmidt 2009), the social welfare model of disability has been predominant. In this system, disability policy is based on important redistributive provisions and on the ambition to maximize participation in paid work. ${ }^{6}$ Employers receive wage subsidies to compensate them for lower productivity related to disability (Burkhauser and Hirvonen 1989). This policy is based on differential treatment of people with disabilities, with specific workplaces and programs to guarantee their inclusion in the paid labor market. Instead of conceiving their inclusion in society as a right, it promotes a "parallel track" for people with disabilities (Heyer 2015). ${ }^{7}$

\section{Table 2. Milestones in Swedish Disability Policy}

1911 The Swedish Central Committee for the Care of Cripples (SVCK) is established.

1924 The Swedish Association for Disabled Persons (DHR) is established.

1955 Universal Health Insurance is introduced.

1962 The National Insurance Act is passed.

1972 The Disability Federation's Central Committee adopts the policy program “One Society for All.”

1994 The Disability Ombudsman (HO) is established and the Act Concerning Support and Service for Persons with Certain Functional Impairments (LSS) is passed.

1999 The Prohibition of Discrimination in Working Life on Grounds of Disability Act is passed.

2000 The Employment Equality Directive is passed by the European Union.

\footnotetext{
${ }^{6}$ Nordic disability protection systems are often considered more generous than others, to the point that some disability scholars have spoken of a "distinct Nordic model" (Lewin, Lewin, Back, and Westin 2008; Hvinden 2004).

${ }^{7}$ In other Western countries, quotas are a tool for implementing a specific policy to maximize participation in paid work (Heyer 2015). Both quotas and wage subsidies are specific provisions for people with disabilities.
} 
2009 The Discrimination Act is passed. The Discrimination Ombudsman (DO) is established.

Source: compiled by the author from the Discrimination Ombudsman annual reports and from various official documents.

In the 1990s, the state tried to expand its role and become a rights-enforcement agency in addition to its mission as a supplier of provisions for people with disabilities. In 1994, after three years of non-socialist government, the Swedish Social Democratic Party won the election and formed a new minority government. That same year, the Disability Ombudsman (Handikapp Ombudsmannen) was created. ${ }^{8}$ This government agency monitored issues related to the rights and interests of people with physical or mental impairments and tried to ensure that people with disabilities were able to fully participate in community life and in the labor market. At the same time, the government passed the Act Concerning Support and Service for Persons with Certain Functional Impairments (LSS), a human rights law promoting equal living conditions for disabled people. A few years later, in 1999, the government passed the first law in Sweden focusing explicitly on discrimination, the Prohibition of Discrimination in Working Life of People on Grounds of Disability Act. This law offered a broadened definition of disability as a "limitation of a person's functional capacity resulting from an injury or illness" and aimed to protect people with permanent physical, psychiatric, or learning disorders against discrimination in the workplace. At that time, Sweden was the first continental European country to give disabled individuals the right to file lawsuits. The Disability Ombudsman oversaw the enforcement of the Act. ${ }^{9}$

However, this rights-based legal framework and broadened definition of disability did not immediately lead to policy change. During the 1990s and early 2000s, in order to reinforce its legitimacy and become recognized as a rights-enforcement agency, the Disability Ombudsman expanded its collaboration with the disability rights movement. From 1994 to 2009, the agency recruited many people with training in social science and social work and long-term experience within the disability movement, whom I identify as "grassroots activists."

In their everyday work for the agency, these former grassroots activists who became bureaucrats mobilized resources from two spheres, the private and the public. On the one hand, as long-term activists, they were used to working in collaboration with disability NGOs. They could not conceive of promoting disability rights or fighting discrimination against workers with disabilities without collaborating with organizations representing and composed of persons with disabilities. In addition to their professional activity, some of them were volunteers in various disability rights organizations.

I worked for the Handikapp Ombudsman (HO) in 1996. I came here when the Discrimination Ombudsman opened, in 2009. [...] Before I was recruited at the HO, and in addition to my work for the agency, I have always been a member of two disability rights organizations. I was even president of the local branch of one of them. I know the field very well, and it was important to be recruited by the HO (Case officer, Discrimination Ombudsman, Stockholm, May 2012).

\footnotetext{
8 This followed the Equality Ombudsman in 1980 and the Ombudsman against Ethnic Discrimination in 1986.

${ }^{9}$ If the Disability Ombudsman considers the case as important for the application of the law or for any other special reason, it can also file a complaint on behalf of the worker or job seeker.
} 
Their personal experience in civil society gives them practical knowledge and expertise in the area of disability. This case officer compared his experience with that of colleagues who had not worked for NGOs prior to joining the government agency:

Before I came here, I worked for a nonprofit organization that helps deaf people to get access to the labor market. I know the nonprofit sector very well, and compared with some of my colleagues I've met lots of people with disabilities in my life. I've talked to them, tried to solve their problems. I know exactly what they experience when they look for a job (Case officer, Discrimination Ombudsman, Stockholm, April 2012).

On the other hand, in their current work in a government agency, they had more resources than when they worked in the non-governmental sector. They believed that their current position enabled them to produce broader social change than is possible with NGOs:

After two years, I thought that I knew everything I could learn from this position in [the NGO where he worked]. [...] And also, if I wanted to change society, the Ombudsman was the organization in which I could do that. If you want to make an impact, you have to be in a large organization. In NGOs, you can help people locally, but it's hard to produce social change (Case officer, Discrimination Ombudsman, Stockholm, May 2012).

These actors saw themselves as long-term activists deeply committed to the disability rights movement. The boundary they placed between their professional position and their personal commitment was vague, as this case officer for the Discrimination Ombudsman explained:

Am I an activist? Of course I am. My commitment to disability rights is what led me to this position. What I do for living is related to what I do as an activist within the disability rights movement. They are connected (Case officer, Discrimination Ombudsman, Stockholm, May 2012).

By recruiting employees who were activists in the disability movement, the Disability Ombudsman was trying to expand its role beyond the supply of provisions for disabled people. It aimed to be recognized as a rights-enforcement agency that guaranteed the effectiveness of the Act on Prohibition of Discrimination in Working Life on Grounds of Disability. To this end, the Disability Ombudsman developed various legal strategies. It processed complaints from individuals who believed they had been discriminated against because of their disability and provided them with assistance. It also monitored employers' compliance with the law. Prior to the creation of the Discrimination Ombudsman in 2009, these various strategies had been poorly organized and institutionalized.

Given that many legal strategies were possible, bureaucrats saw themselves as having the opportunity to select from a wide range of strategies in pursuing changes in society and policy. They could exercise a great deal of discretion in the execution of their work because they had many options available when determining how they wanted to enforce the law.

Before 2009, we had many options. Everything was open. The procedures were not defined yet. Maybe it was dangerous, but we had more opportunities to work proactively or reactively to fight discrimination (Case officer, Discrimination Ombudsman, Stockholm, May 2012).

The first phase in the development of the relationship between the disability movement and the state was thus characterized by the expansion of the state's intervention as well 
as by important collaborations with nonprofit organizations. These partnerships served to define proactive measures to promote the full participation and inclusion of disabled workers as well as measures to assist victims of discrimination.

\section{NGOs at a distance: strategic litigation and legal professionalization (2009-2012)}

During the second phase in the development of the relationship between the disability movement and the state, the Ombudsman tried to become indispensable to the enforcement of antidiscrimination policy in the country. In 2006, the center-right parties won the election and formed a government coalition called Alliance. This election led to political changes in the institutional collaboration between the state agency and nonprofit organizations. At this time, the government agency started to pursue litigation as its main strategy and to distance NGOs from its activity.

In 2008, Sweden adopted the Discrimination Act, which transposed the 2000 European Employment Equality Directive into national law. This new law gave the state an opportunity to reinforce its disability policy role. First, the Discrimination Act created a new agency, the Discrimination Ombudsman (DO), which merged four ombudsmen: the Disability Ombudsman and three others. ${ }^{10}$ The Discrimination Ombudsman gained the authority to fight all types of discrimination and to promote civil rights and equality in all the areas of social life. ${ }^{11}$ This new agency received significant financial support from the state when it opened in 2009. Second, the Discrimination Act also broadened the agency's authority. Conforming to the rights model advocated by the Employment Equality Directive and the UN Convention on the Rights of Persons with Disabilities, ${ }^{12}$ the Discrimination Act relied on a litigation model that enforced substantive antidiscrimination regulations and encouraged the Discrimination Ombudsman to use the courts to produce social change both at the national and supranational levels. In this sense, antidiscrimination law and policy created new legal instruments and resources for tackling disability discrimination and provided disabled individuals, nonprofit organizations, and the Ombudsman with new opportunities to challenge discriminatory practices before national and European courts (De Witte 2010; Guiraudon 2009; Carlson 2007; Conant 2002). ${ }^{13}$

During this period, the Discrimination Ombudsman equipped itself with significant resources and expertise to develop the new policy and to comply with the litigation strategy promoted by the Discrimination Act. The agency recruited many "in-house lawyers" and legal professionals to support the development of the litigation strategy (Diskrimineringsombudsmannen, 2011). Compared with the grassroots activists previously recruited to the Disability Ombudsman, those I refer to as "human rights

\footnotetext{
10 The Ombudsmen against discrimination on the grounds of ethnicity, sex, and sexual orientation.

11 In Sweden, the Antidiscrimination Act identifies six grounds of discrimination: sex, ethnicity, age, religious beliefs, sexual orientation, and disability.

12 Some scholars argue that the 1999 Treaty of Amsterdam marked a shift in disability policy in Europe, even though it treated disability as a civil rights issue (Waldschmidt 2009).

13 Unlike the Equal Employment Opportunity Commission in the United States, the Swedish Discrimination Ombudsman is not competent to organize quasi-judicial procedures (administrative trials) issuing legally binding decisions. Litigation is the only mean to assist individuals who file discrimination complaints.
} 
lawyers" had few connections with the disability rights movement. This new generation of professionals has been recruited over the past decade, mostly since 2008 when the Discrimination Act was passed. They are usually younger than the grassroots disability activists and are recruited by the government agency because they have a law degree and an interest in human rights. Most of them have already practiced law in the courts as lawyers in private practice or as judges.

I've been working as a litigation officer since 2009. [...] I studied law in university. When I finished my studies, I worked for a couple of years as an assistant judge in the court. It was the first step to becoming a judge, but then I was recruited here (Litigation officer, Discrimination Ombudsman, Stockholm, April 2012).

From 2009 to 2012, the agency underwent a process of legal professionalization of the treatment of disability disputes and issues. At that time, the vast majority of staff worked in the litigation department, which was the largest in terms of human and material resources. Most of the manpower was thus dedicated to receiving complaints from individuals who believed they had been subjected to discrimination. In their everyday work for the agency, lawyers investigated places of work, collected evidence, and brought cases before the labor court.

When the Ombudsman decides to take a case to court and to represent an individual in the court, it's me. I take the case to court, and that's my main line of work. But I'm also involved in other tasks: I help the investigators, who can come to me and I give them advice. How should they investigate the case? What evidence do we need? Should we stop the investigation because this isn't going to be a good court case anyway? Those kinds of things. (Litigation officer, Discrimination Ombudsman, Stockholm, April 2012).

These lawyers had few connections with the disability movement. However, they viewed themselves as cause lawyers, meaning legal professionals who wanted to use their legal expertise and trial experience to serve a cause they believed in and build a better society (Sarat and Scheingold 1998). They usually linked their commitment to their professional skills as legal experts; they could not conceive of the former without the latter. They tended to view themselves as human rights lawyers in general rather than as disability activists in particular.

I would say that I don't know if I'm an activist... I'm a legal professional and my job is to enforce the Discrimination Act. My job is to go to court, because that's where we can fight discrimination and change the lives of disabled workers (Legal expert, Discrimination Ombudsman, Stockholm, May 2012).

From 2009 to 2012, the Discrimination Ombudsman mostly developed a strategy of social change through litigation. To comply with antidiscrimination law and to monitor compliance with the statutory prohibitions against discrimination, the first head of the agency, a lawyer, decided that it should investigate all complaints by citizens who believed that they had been subjected to discrimination and should take as many cases to the labor court as possible in order to promote social change.

When the Discrimination Ombudsman was created in 2009, our general director thought that we could change society by taking lots of cases to courts. That was the idea. To fight discrimination, we believed that we had to accommodate everyone who wanted to complain and to bring lots and lots of cases to court (Case officer, Stockholm, April 2012). 


\begin{tabular}{|c|c|c|c|c|}
\hline Case & Start & End & Issue & Result \\
\hline $\begin{array}{l}\text { Lessebo } \\
\text { Municipality }\end{array}$ & 2009 & 2009 & Partially deaf woman is denied work. & $\begin{array}{l}\text { Settlement } \\
35000 \mathrm{SEK}(\$ 4300)\end{array}$ \\
\hline Borås Municipality & 2008 & 2009 & $\begin{array}{l}\text { Woman with chronic backache is denied } \\
\text { a promotion due to high absenteeism. }\end{array}$ & $\begin{array}{l}\text { Settlement } \\
50000 \mathrm{SEK}(\$ 6150)\end{array}$ \\
\hline CNET & 2008 & 2009 & $\begin{array}{l}\text { Pregnant woman with diabetes is } \\
\text { dismissed because of her state of health } \\
\text { (discrimination based on disability and } \\
\text { gender). }\end{array}$ & $\begin{array}{l}\text { Settlement } \\
65000 \mathrm{SEK} \\
(\$ 8000)\end{array}$ \\
\hline Fitness New York & 2007 & 2009 & $\begin{array}{l}\text { Mentally disabled woman is denied } \\
\text { reasonable accommodation of her } \\
\text { schedule. }\end{array}$ & $\begin{array}{l}\text { Settlement } \\
45000 \mathrm{SEK}(\$ 5550)\end{array}$ \\
\hline $\begin{array}{l}\text { Social Insurance } \\
\text { Agency }\end{array}$ & 2006 & 2010 & $\begin{array}{l}\text { Woman with visual impairment is } \\
\text { denied a job because the company } \\
\text { cannot adapt her workplace (computer } \\
\text { in Braille). }\end{array}$ & $\begin{array}{l}\text { Labor Court - } \\
\text { Lost } \\
\text { The company has } \\
\text { no duty to adapt a } \\
\text { computer program }\end{array}$ \\
\hline Local Info & 2009 & 2010 & $\begin{array}{l}\text { Woman with rheumatism is denied a } \\
\text { permanent work contract. }\end{array}$ & $\begin{array}{l}\text { Settlement } \\
\text { 100000SEK } \\
(\$ 12300)\end{array}$ \\
\hline Caring Company & 2009 & 2011 & $\begin{array}{l}\text { Man with visual impairment is denied a } \\
\text { job. }\end{array}$ & $\begin{array}{l}\text { Labor Court - } \\
\text { Lost } \\
\text { The man cannot } \\
\text { perform the } \\
\text { necessary tasks }\end{array}$ \\
\hline $\begin{array}{l}\text { Veolia Transport } \\
\text { Sweden AB }\end{array}$ & 2011 & 2013 & $\begin{array}{l}\text { A bus driver's long-term sickness is not } \\
\text { accommodated. }\end{array}$ & $\begin{array}{l}\text { Labor Court - } \\
\text { Lost }\end{array}$ \\
\hline
\end{tabular}

Source: compiled by the author from the Discrimination Ombudsman's court records database.

The bureaucrats believed they had substantial discretion in the execution of their work because they had the opportunity to determine their legal strategies through interaction with the public. But in a system primarily based on litigation, the agency was highly dependent on the complaints sent by individuals who believed they had been subjected to discrimination. The lawyers who worked for the agency saw the lack of legally relevant complaints as the main barrier to promoting rights through litigation.

In the litigation activity, we decide if we investigate a case, if we call the employer, if we go to court. We have lots of freedom to decide the best way to support the case. The only problem we have is receiving good complaints. If you don't have any good complaints, it reduces the opportunity to do something great (Litigation officer, Discrimination Ombudsman, May 2012).

In this context, the agency needed to receive "good complaints" in order to have a broader range to choose from when selecting complaints compatible with its legal strategy. Collaboration with antidiscrimination centers-which are nonprofit, local human rights and equal opportunity organizations (Rättighetscenter)—and with other nonprofit organizations specializing in disability rights was useful for receiving good complaints. Since these organizations were receiving less public financial support every year due to policy changes enacted by the majority center-right government, they did 
not have the legal and financial resources to take cases to the labor court. In this context, they advised people to lodge a complaint with the Discrimination Ombudsman, and then they assisted them with this process. These collaborations between the agency and NGOs were relatively weak, and were always limited to exchanges on individual complaints. Furthermore, the relationship between these governmental and nongovernmental organizations was also based on competition. Legal professionals from these NGOs stressed the ambiguities in their collaboration with the Discrimination Ombudsman. A legal advisor to the antidiscrimination centers highlighted the insufficiency of their financial resources and the fact that their work lacked recognition in the shadow of legal institutions. Although she viewed herself as a legal advisor with the legal skills and expertise to go to court and fight discrimination, she thought that she was doing the Discrimination Ombudsman's "dirty-work" (Hughes 1996) and that the work her nonprofit organization did during the trial went unrecognized.

The collaboration with the DO should be positive, but as things stand, it is problematic because the DO has lots of resources and we don't. And we're not paid for what we do for the DO. Because of our history and status as a nonprofit organization, we're supposed to be a free service. But we don't have many financial resources. If we send a case to the DO, and then they take it to court and win a case, they will get compensation, even if we did all of the case preparation. And we ourselves don't earn anything because we're not supposed to work for the Discrimination Ombudsman. (Legal advisor, antidiscrimination center, Malmö, May 2012)

During the second period, litigation became the main strategy of the Discrimination Ombudsman, whose bureaucrats underwent a process of legal professionalization. In this context, the NGOs were kept at a distance. The relationships between the agency and the NGOs became very asymmetrical and limited to collaboration on individual cases and based on competition more than cooperation.

\section{Various forms of collaboration: fostering organizational compliance with the law (2012-2014)}

Three years after the creation of the Discrimination Ombudsman, the agency was criticized: many members of nonprofit and disability rights organizations criticized the lack of support for individuals who faced discrimination based on disability, labor unions challenged the separation of workers into different groups of protected minorities, and labor judges were not in favor of disability discrimination cases being brought before the labor court. Furthermore, the agency had limited access to the labor court, as the labor unions strictly limited its jurisdiction. In this context, the litigation strategy was viewed as inadequate for promoting the rights of people with disabilities on the national labor market.

In 2011, the government called on the Discrimination Ombudsman to resign as head of the agency. The report of the National Audit Office in 2012 highlighted various problems in the agency. "The overall picture is that the Discrimination Ombudsman has put substantial resources into handling discrimination cases received from individuals. This has affected the DO's ability to proactively combat discrimination and oversee active measures" (General Auditor, in the National Audit Office Report, 2012). In this context, the agency underwent significant organizational change. A former judge became the new Discrimination Ombudsman. He decided to take the agency's activity in a different direction. Instead of investigating all complaints, the agency now selected the cases most likely to produce case law before the labor court. After the Discrimination Ombudsman 
decided to reduce its litigation activity, the agency strengthened other legal strategies for enforcing the Discrimination Act in the Swedish labor market. The main new strategy aimed to raise awareness of disability rights among employers and workers in order to make them more responsive to antidiscrimination laws. They mobilized the law in order to force employers to adopt employee training programs and diversity plans, to create new management structures, or to change their recruitment process in order to foster greater organizational compliance with the law.

In implementing this new strategy, one of the main points of contention within the Ombudsman concerned the opportunity to reinforce collaborations with the disability movement. The grassroots activists among the bureaucrats believed they needed to work with disability rights organizations to gain knowledge about the everyday discrimination experiences faced by people with disabilities. When they forced employers to comply with the law, they needed to know exactly what kinds of barriers workers with disabilities faced when trying to access employment and what their specific needs were. Conversely, human rights lawyers, who had few connections with NGOs and organizations for disabled people, believed that law enforcement should solely be the agency's prerogative, outside of any partnership with nonprofit organizations.

I was recruited as a litigation officer. I'm now organizing training. The main change, and the main problem I face right now is that I'm supposed to work with nonprofit organizations and I've never done that before. I'm a lawyer, I'm used to litigating, not being an activist (Policy officer, Discrimination Ombudsman, April 2012).

The Discrimination Ombudsman's collaboration with disability rights organizations took various forms. It all depended on the bureaucrats involved and on their connections with the disability movement. In this context, the bureaucrats believed that they had less opportunity to define how they mobilized the law to produce social change now that their primary role was to foster organizational compliance with the law. Previously, the public with whom they interacted was mostly made up of disabled individuals making rights claims. Now they dealt mainly with human resources and diversity managers from private companies or public organizations. They believed that their legal strategies had become routine in every organization.

When you listen to someone who has experienced discrimination, you learn many things about his or her personal history, and you have to find ways to satisfy the person. [...] When you spend lot of time with HR, it's very different. You just explain the law, and try to make them aware of discrimination law. It's the same task every day, even if you visit several companies (Case officer, Discrimination Ombudsman, April 2012).

During this third and last period in the development of the relationship between the disability movement and the state, the Discrimination Ombudsman tried to promote its image as an impartial and neutral organization. With this new strategy, the Discrimination Ombudsman was able to routinize its legal activity with employers.

\section{DISCUSSION: LEGAL MOBILIZATION WITHIN THE BUREAUCRACY}

This paper has shown that two dimensions are important for understanding the exchanges and interconnections between social movements and the state and legal mobilization within the bureaucracy. On the one hand, the state's institutional relationships with nongovernmental organizations, which vary over time, influence legal 
mobilization within the bureaucracy (1). On the other hand, the transfer, expertise, and professional socialization of agents, as well as their connections with the disability rights movement, also shape how legal mobilization proceeds (2).

\section{Collaboration and competition: How institutional relationships with NGOs shape legal mobilization within the bureaucracy}

From within the Discrimination Ombudsman, bureaucrats challenge certain dominant conceptions of workplace regulation in Sweden, with the direct effect of forcing organizational change. In this sense, like social movements, the state agency also participates in mobilizing the law to influence policy or behavior and to challenge rights violations. Two variables are important for understanding how the institutional relationships between government agencies and NGOs shape legal mobilization within the bureaucracy.

First, the system of institutional relationships between the state and civil society organizations is significant. Sweden is a neocorporatist system in which NGOs and the state tend to avoid all forms of conflicts. As is expected, the Discrimination Ombudsman puts particular effort into collaboration and negotiation with disability rights organizations. These groups take part in defining and implementing the agency's activities. Consensus decision making is the rule, and the Ombudsman mostly defines itself as a partner or ally of civil society organizations, not as their opponent. Legal mobilization within the state is of course different from mobilization of the law by private groups and individuals because the Ombudsman has to legitimize and control its position as a government agency as well as its relationships with other actors who play a role in promoting the rights of people with disabilities in the country. However, civil society organizations usually help the Discrimination Ombudsman conduct its legal activities, both inside and outside the courtroom.

In some recent cases, the state has supported social movements' demands. The agency has the financial resources to file lawsuits in the labor court and enforce the law, whereas nonprofit organizations have a very limited budget for legal action. ${ }^{14}$ Furthermore, bureaucrats are also skilled in legal issues, with significant experience with trials and specific knowledge about antidiscrimination law. Conversely, the agency needs to collaborate with nonprofit organizations in order to receive more complaints from individuals who have experienced discrimination based on disability or to take advantage of their disability expertise. In short, the system of institutional relationships between the state and civil society organizations in Sweden favors cooperation and collaboration between the agency and disability rights organizations.

A second factor also orients the Ombudsman's legal activity: the variation in how the state agency defines its role and identity in its field over time. Analysis of changes to disability policy in Sweden shows that relationships between disability rights organizations and the state are not consistent over time. Even in a neocorporatist system, the government agency sometimes clashes with nonprofit organizations over the definition and implementation of public policy. As I explained earlier, the existing literature on relationships between civil society organizations and the state has primarily focused on NGOs. It has explained "such groups' own understandings of their

14 In 2013, the budget of the agency was 94,356,000 Swedish Krona, which corresponds to more than 11 millions dollars. 
purposes, identities, and sense of membership over time" (Morag-Levine 2003, 462) and how this shapes their legal mobilization. Studying disability rights in Sweden gives us an opportunity to further explore other actors involved in the relationship-state agencies and bureaucracies - and to examine how they define their identity and role within the disability rights field.

In its recent history, the state agency has sometimes opposed social movements' demands. Bureaucrats I interviewed saw this opposition as a strategy to maintain the Ombudsman's specific position within the disability rights field. They mentioned one primary challenge in their day-to-day work with antidiscrimination law that reveals the complex relationships between social protests and institutions. As a state agency, they have the formal authority to enforce antidiscrimination law, while civil society organizations do not have this power. For this reason, in some situations they believe that the agency should distance itself from NGO demands and remain neutral and impartial. For instance, in several recent individual cases, mostly concerning religious expression in the workplace, the agency's decision to file lawsuits has been widely discussed and criticized in the media and the public arena. In the disability cases brought before the labor court, the political debate was less virulent, but they never resulted in a favorable decision from the labor judges, who did not follow the definition of discrimination supported by the Ombudsman.

The political orientations of successive governments partially explain the evolution of relationships between the Discrimination Ombudsman and disability rights organizations. From 1994 to 2006, when the left-wing parties held a majority, collaboration with NGOs was encouraged. In 2006, a center-right coalition won the general election. From 2006 to 2014, this majority coalition encouraged the Discrimination Ombudsman to distance itself from NGOs in order to reinforce the agency's independence from the mobilizations of civil society. Another factor that helps explain the variations in how the state agency defines its identity within the disability rights field are changes in social policy relating to disability. In the rights-based model promoted by antidiscrimination law, the state gives disabled individuals the right to litigate in order to protect their individual rights rather than promoting the collective interests of people with disabilities. This change in disability policy in Sweden and this new orientation towards litigation have caused increased conflict between disability rights organizations and the state. Disability rights organizations consider, as Anne Orford has shown, that "adversarial legalism is what remains when the state no longer attends to the interests of the people who live within its territory, leaving individual 'consumers' to litigate in an attempt to protect their 'rights'” (Orford 2012, 286).

As in other social policy areas in Sweden and elsewhere in Europe, such as access to healthcare services, this case shows that institutional reforms alter the state's relationships with civil society organizations and change the focus and execution of bureaucrats' work.

\section{Grassroots activists, human rights lawyers, or bureaucrats? How individual careers shape legal mobilization}

The second dimension that influences and shapes legal mobilization is the professional background and socialization of the bureaucrats working for the agency. As the missions of the Ombudsman have evolved over time, the profiles of the bureaucrats have been very diverse. This situation leads to bureaucrats holding different understandings of 
their roles, values, norms, ethical standards, and commitment to disability rights. The agency is thus not a monolithic actor but rather an institution with different segments that influence the provision of government services.

In their everyday work, bureaucrats develop different strategies, varying the extent to which they enforce the laws assigned to them. There are two generations of bureaucrats, and these two groups have not developed the same strategies. There is a sharp division between those who reject conflicts with the disability rights movement and those who view these conflicts as a necessary check on the independence of the state agency. ${ }^{15} \mathrm{On}$ the one hand there are grassroots activists who have connections with both worldsprivate and public-because they used to work for private organizations and then moved into a government institution. They maintain close relationships with the disability movement and are more likely than their younger colleagues to follow or reinforce the legal strategies of social movements. For this reason, they can be viewed as "transfer agents" who contribute to reinforcing the collaboration and blurring the boundary between the government agency and the disability movement. When the Discrimination Ombudsman developed a litigation-based strategy from 2009 to 2012 and encouraged bureaucrats to distance NGOs from the agency's activity, the first generation of bureaucrats resisted organizational change by maintaining close connections with the nonprofit organizations for which they used to work, even though they were supposed to limit their collaboration to the investigation of individual cases. They viewed these interactions with civil society as vital for the prevention of conflicts and litigation. In this sense, as observed by Charles Epp in various bureaucracies in the United States (Epp 2009), they responded to the political and social demands of civil society groups and integrated the norms and values of progressive reformers from disability rights organizations into bureaucratic practices.

On the other hand, bureaucrats recruited as human rights lawyers have few connections with the disability rights movement. Since their primary mission is to bring cases to the courtroom, their collaboration with nonprofit organizations is limited, only concerning individual cases. They believe that the Ombudsman, as a state agency, should distance itself from social movements' organizations in order to preserve its independence. In this sense, they are more likely than the older generation of bureaucrats is to develop strategies that oppose social movements' demands. For instance, the legal staff of the Discrimination Ombudsman decided not to handle some recent discrimination cases sent to them by disability rights organizations because there was insufficient evidence. In their everyday practice, this younger generation of "in-house lawyers" tries to resist current organizational changes that encourage organizational compliance with the law and focus instead on performing tasks that lawyers consider more closely related to their professional training and identity. For instance, as one litigation officer stated, when he meets workers during training sessions in private companies, he is able to go beyond his assigned tasks by encouraging them to file a complaint with the Discrimination Ombudsman if he believes they have been subjected to discrimination and by helping them collect evidence and develop their legal argument.

These everyday practices show that bureaucrats often circumvent or compromise with the formal orientation of the Discrimination Ombudsman. Their substantial discretion in

\footnotetext{
15 In her analysis of two conservationist organizations and their relationship with the governments in the United States and Israel, Noga Morag-Levine has developed the same idea about nongovernmental organizations: she has highlighted the generational divisions in how lawyers engage with bureaucrats (Morag-Levine 2003).
} 
the execution of their work, as well as the public with whom they interact, have evolved and changed over time. Among the bureaucrats, two group profiles have been highlighted with two main differences. First, their conception of their work with antidiscrimination law and disability rights organizations dissimilarly influences the meaning they attach to their mobilization of the law. Second, as Hunter et al. have shown, their differentiated legal abilities and propensities influence the way they implement the law (Hunter, Bretherton, Halliday, and Johnsen 2016). This article confirms that those individuals are central to the meaning and application of policy. It shows that the agency of legal activists and bureaucrats matters (Vanhala 2012) because, in the same context and with the same resources, they have different options, and their choices influence how and why they mobilize the law.

\section{CONCLUSION}

To study the relationship between law, social movements, and the state, as well as the role of the state as a legal mobilization actor, this article has examined how disability activists and bureaucrats in Sweden mobilize antidiscrimination law to promote the inclusion and full participation of disabled people in the labor market.

Broadening the scope of legal mobilization and social movement literature, this paper suggests giving attention to the legal activity of bureaucrats. It shows that social and political protests can also take place within the core institutions of the state because bureaucrats, like social movement activists, also contribute to challenging certain dominant conceptions of workplace regulation in Sweden and aim to have a direct effect and force organizational change. From this perspective, they also participate in mobilizing the law to influence policy or behavior and to challenge rights violations.

In the recent history of disability policy in Sweden, three periods of cooperation and competition between the bureaucracy and nongovernmental organizations can be distinguished. Each period corresponds to the implementation of different legal strategies and different types of legal mobilization. The first period was characterized by the creation of the first government disability agency in Sweden and by cooperation with the nongovernmental sector to expand the intervention of the state, broadening its role from that of a provision supplier to that of a disability rights agency. The second period began in 2009 with the passing of the Discrimination Act. This period was characterized by the legal professionalization of the disability movement and the development of litigation as the primary strategy for promoting access to the labor market for people with disabilities. At that time, the Ombudsman supplied resources for litigation, but the agency's collaboration with the nonprofit sector was limited to individual cases. The third period, starting in 2012, was characterized by the desire to expand legal strategies beyond the courtroom and to foster organizational compliance with the law. At that time, collaboration with NGOs was controversial within the agency.

Given that legal mobilization policy remains largely under-examined in contexts outside of the United States and common law countries (Kawar 2011), the analysis of the Swedish case raises two important questions for further research on legal mobilization. First, from the mesolevel perspective, it invites us to give more attention to the state, its relationship with social movements, and its role in legal mobilization in nonpluralist countries. This paper has shown that institutional collaboration between government agencies and nongovernmental organizations, and the variation of this collaboration 
over time, are important for understanding the role of the bureaucracy in legal mobilization. Building upon other studies on legal mobilization in corporatist countries (Vanhala 2016; Soennecken 2013), it has argued that state agencies prefer cooperation over conflict with civil society organizations and that, for this reason, the activity of bureaucrats is shaped by social movements' demands. It would be relevant to broaden the analysis to other areas of mobilization in other European countries with a view to better developing a theoretical perspective on legal mobilization in nonpluralist countries, giving particular attention to the role of the state as a partner of social movement organizations.

Second, on the microlevel of analysis, Sweden shows the need to pay attention to the meaning that agents attribute to legal mobilization inside and outside the courtroom in rights-establishment landscapes. Although civil society actors may not give priority to litigation in promoting the rights of disabled workers, the EU's antidiscrimination directives, following a model of adversarial legalism, clearly encourage the national agencies of member states to expend their litigation-based policies (Kelemen 2011). For this reason, the relevance of litigation is a subject of constant debate among activists and bureaucrats in the disability field in Sweden. Given that the recruitment practices and compositions of bureaucracies shape legal mobilization behavior, this paper suggests that it would be fruitful to more closely examine the agents who implement antidiscrimination norms both inside and outside the state, studying their professional backgrounds and connections with the disability movement in order to understand how bureaucracies can be sites of legal mobilization.

Aude Lejeune is CNRS Faculty Research Fellow in political sociology at the University of Lille. She was Fulbright visiting fellow at MIT Anthropology in 2012. Her research focuses on legal mobilization in different contexts. She has published a book, Le droit au droit. Les juristes et la question sociale en France (EAC, 2011), and several articles in peer-reviewed journals, including "The Construction of Workers' Rights Consciousness through Legal Intermediations" (with Orianne J.-F.), International Journal of Discrimination and the Law, 14 (4): 221-243. 


\section{REFERENCES}

Andersen, E. A. 2006. Out of the Closests and Into the Courts: Legal Opportunity Structures and Gay Rights Litigation. Ann Arbor: University of Michigan Press.

Banaszak, L. A. 2009. The Women's Movement Inside and Outside the State. Cambridge: Cambridge University Press.

Barclay, S., L. Jones, and A. -M. Marshall. 2011. "Two Spinning Wheels: Studying Law and Social Movements," Studies in Law, Politics and Society 54: 1-17.

Barnes, J., and T. Burke. 2012. "Making Way: Legal Mobilization, Organisational Response, and Wheelchair Access," Law \& Society Review 46 (1): 167-198.

Baudot, P.-Y., and A. Revillard. 2014. "Entre mobilisations et institutions. Les politiques des droits dans l'action publique," Gouvernement et Action Publique 3 (4): 9-33.

Baudot, P.-Y., and A. Revillard (eds.). 2015. L'Etat des Droits. Politique des droits et pratiques des institutions. Paris: Presses de Science Po.

Bereni, L., and A. Revillard. 2012. "Un mouvement social paradigmatique? Ce que le mouvement des femmes fait à la sociologie des mouvements sociaux," Sociétés Contemporaines 85: 17-41.

Berenson, S. 2009. "Goverment Lawyer as Cause Lawyer: A Study of Three High Profile Government Lawsuits," Denver Law Review 86 (2): 457-508.

Black, D. 1973. "The Mobilization of Law," Journal of Legal Studies 2: 125-149.

Bumiller, K. 1987. "Victims in the Shadow of the Law: A Critic Model of Legal Protection," Signs 12 (3): 421-439.

Burke, T. 2004. "The European Union and the Diffusion of Disability Rights." In Translating Policy-Making in an Age of Austerity: Diversity and Drift, edited by M. Levin and M. Shapiro, 158176. Washington DC: Georgetown University Press.

Burke, T. 2015. "The Americans with Disabilities Act As a Litigation Policy." Paper presented at the conference "2005-2015: quel anniversaire pour les personnes handicapées en France?," Paris.

Burkhauser, R., and P. Hirvonen. 1989. "United States Disability Policy in a Time of Economic Crisis: A Comparison with Sweden and the Federal Republic of Germany," The Milbank Quarterly 67 (2): 166-194.

Burstein, P. 1991. "Legal Mobilization as a Social Movement Tactic: The Struggle for Equal Employment Opportunity," The American Journal of Sociology 96 (5): 1201-1225.

Carlson, L. 2007. Searching for Equality: Sex Discrimination, Parental Leave, and the Swedish Model with Comparisons to EU, UK, and US Law. Stochkolm: Coronet Books.

Cichowski, R. 2013. "Legal Mobilization, Transnational Activism, and Gender Equality in the EU," Canadian Journal of Law and Society / Revue Canadienne Droit et Société, 28 (2): 209-227.

Conant, L. 2002. Justice Contained: Law and Politics in the European Union. Ithaca: Cornell University Press.

De Witte, B. 2010. "From a 'Common Principle of Equality' to 'European Antidiscrimination Law,'" American Behavioral Scientist 53 (12): 1715-1730.

Diskrimineringsombudsmannen. 2011. Annual Report, 82. Stockholm.

Engel, D., and F. Munger. 2003. Rights of Inclusion: Law and Identity in the Lives of American with Disabilities. Chicago: University of Chicago Press.

Epp, C. 1998. The Rights Revolution: Lawyers, Activists, and Supreme Courts in Comparative Perspective. Chicago and London: University of Chicago Press. 
- - . 2009. Making Rights Real: Activists, Bureaucrats, and the Creation of the Legalistic State. Chicago: University of Chicago.

Etherington, D., and J. Ingold. 2012. "Welfare to Work and the Inclusive Labour Market: A Comparative Study of Activation Policies for Disability and Long-Term Sickness Benefit Claimants in the UK and Denmark," Journal of European Social Policy 22 (1): 30-44.

Ewick, P., and S. S. Silbey, S. S. 1998. The Common Place of Law: Stories from Everyday Life. Chicago: University of Chicago Press.

Felstiner, W., R. Abel, and A. Sarat. 1981. "The Emergence and Transformation of Disputes: Naming, Blaming, Claiming...," Law \& Society Review 15 (3/4): 631-654.

Fuller, S., L. Edelman, and S. Matusik. 2000. "Legal Readings: Employee Interpretation and Mobilization of Law," Academy of Management Review 25 (1): 200-216.

Guiraudon, V. 2009. "Equality in the Making: Implementing European Non-discrimination Law," Citizenship Studies 13 (5): 527-548.

Heyer, K. 2015. Rights Enabled. The Disability Revolution, from the US, to Germany and Japan, to the United Nations. Ann Arbor: University of Michigan Press.

Hilson, C. 2002. "New Social Movements: the Role of Legal Opportunity," Journal of European Public Policy, 9 (2): 238-255.

Hirsh, E., and S. Kornich. 2008. "The Context of Discrimination: Workplace Conditions, Institutional Environments, and Sex and Race Discrimination Charges," American Journal of Sociology, 113 (5): 1394-1432.

Hugemarka, A., and C. Roman. 2007. "Diversity and Divisions in the Swedish Disability Movement: Disability, Gender, and Social Justice," Scandinavian Journal of Disability Research 9 (1): 26-45.

Hughes, E. C. 1996. Le regard sociologique. Essais choisis. Paris: Ed. de l'EHESS.

Hunter, C., J. Bretherton, S. Halliday, and S. Johnsen. 2016. "Legal Compliance in Street-Level Bureaucracy: A Study of UK Housing Officers," Law \& Policy 38 (1): 81-95.

Hvinden, B. 2004. "Nordic Disability Policies in a Changing Europe: Is There Still a Distinct Nordic Model?,"Social Policy \& Administration 38 (2): 170-189.

Israël, L. 2009. L'arme du droit. Paris: Presses de Science Po.

Johnston, H. 2010. States and Social Movements. Cambridge: Polity Press.

Katzenstein, M. 1998. Faithfull and Fearless: Moving Feminist Protest Inside the Church and Military. Princeton: Princeton University Press.

Kawar, L. 2011. "Legal Mobilization on the Terrain of the State: Creating a Field of Immigrant Rights Lawyering in France and the United States," Law \& Social Inquiry 36 (2): 354-387.

Kelemen, D. R. 2011. Eurolegalism: The Transformation of Law and Regulation in the European Union. Cambridge: Harvard University Press.

Lejeune, A. 2013. "Legal Mobilization against Workplace Discrimination in Belgium and Sweden: Transnationalism and Convergence in Internal Decision-Making?," Joint-Session "Legal Mobilization: Europe in Comparative Perspective", European Consortium for Political Research (ECPR), Mainz.

Lejeune, A., and J.-F. Orianne. 2014. "The Construction of Workers' Rights Consciousness through Legal Intermediations: The Case of Employment Discrimination in Belgium," International Journal of Discrimination and the Law 14 (4):221-243.

Lewin, L., B. Lewin, H. Back, and L. Westin. 2008. "A Kinder, Gentler Democracy? The Consensus Model and Swedish Disability Politics," Scandinavian Political Studies 31 (3): 291-310. 
Lindqvist, R. 2000. "Swedish Disability Policy: From Universal Welfare to Civil Rights?," European Journal of Social Security 2 (4): 399-418.

Lindvall, J., and J. Sebring. 2005. "Policy Reform and the Decline of Corporatism in Sweden," West European Politics 28 (5): 1057-1074.

Lipsky, M. 2010 (1980). Street-Level Bureaucracy: Dilemmas of the Individual in Public Services. New York: The Russell Sage Foundation.

Marshall, A.-M. 2003. "Injustice Frames, Legality, and the Everyday Construction of Sexual Harassment," Law and Social Inquiry 28 (3): 659-689.

McBride, D., and A. Mazur. (eds.). 2010. The Politics of State Feminism: Innovation in Comparative Research. Philadelphia: Temple University Press.

McCann, M. 1994. Rights at Work: Pay Equity Reform and the Politics of Legal Mobilization. Chicago: University of Chicago Press.

McCann, M. (ed.). 2006. Law and Social Movements. London and Burlington: Ashgate Publishing.

Michailakis, D. 2000. "Ability, inability, disability, and anti-discrimination law," Scandinavian Journal of Disability Research 2 (2), 32-62.

Morag-Levine, N. 2003. "Partners No More: Relational Transformation and the Turn to Litigation in Two Conservationist Organizations," Law \& Society Review, 37 (2): 457-510.

NeJaime, D. 2012. "Cause Lawyers Inside the State," Fordham Law Review, 81 (2): 649-704.

Nolette, P. 2015. "Law Enforcement as Legal Mobilization: Reforming the Pharmaceutical Industry Through Government Litigation," Law \& Social Inquiry 40 (1): 123-151.

Orford, A. 2012. "Europe Reconstructed," The Modern Law Review 75 (2): 275-286.

Pedriana, N., and R. Stryker. 2004. "The Strength of a Weak Agency: Enforcement of Title VII of the 1964 Civil Rights Act and the Expansion of State Capacity, 1965-1971," The American Journal of Sociology 110 (3): 509-560.

Polletta, F., and J. Jasper. 2001. "Collective Identity and Social Movements," Annual Review of Sociology 27: 283-305.

Revillard, A. 2016. "Social Movements and the Politics of Bureaucratic Rights Enforcement: Insights from the Allocation of Disability Rights in France," Law and Social Inquiry, early view, http://onlinelibrary.wiley.com/doi/10.1111/lsi.12174/epdf.

Rothstein, B. 1988. "State and Capital in Sweden: The Importance of Corporatist Arrangements," Scandinavian Political Studies 11 (3): 235-260.

Sarat, A., and S. Scheingold (eds.). 1998. Cause Lawyering: Political Commitments and Professionnal Responsibilities. New York: Oxford University Press.

Sarat, A., and S. Scheingold (eds.). 2005. The Worlds Cause Lawyers Make: Structure and Agency in Legal Practice. Stanford: Stanford University Press.

Sarat, A., and S. Scheingold (eds.). 2006. Cause Lawyering and Social Movements. Stanford: Stanford University Press.

Scheingold, S. 2004 (1974). The Politics of Rights: Lawyers, Public Policy and Political Change. New Haven and London: Yale University Press.

Soennecken, D. 2013. "Theorizing Legal Mobilization: Refugee NGOs in Germany." Paper presented at the joint-session, "Legal Mobilization: Europe in Comparative Perspective," European Consortium for Political Research (ECPR), Mainz.

Southworth, A. 2000. "The Rights Revolution and Support Structures for Rights Advocacy," Law \& Society Review 34 (4): 1203-1219. 
Talesh, S. 2015. "Legal Intermediaries: How Insurance Companies Construct the Meaning of Compliance with Antidiscrimination Laws," Law \& Policy 37 (3), 209-239.

Vanhala, L. 2009. "Anti-discrimination Policy Actors and Their Use of Litigation Strategies: The Influence of Identity Politics," Journal of European Public Policy, 16 (5), 738-754.

2011. Making Rights a Reality? Disability Rights Activists and Legal Mobilization. Cambridge: Cambridge University Press.

- - - 2012. "Legal Opportunity Structures and the Paradox of Legal Mobilization by the Environmental Movement in the UK," Law \& Society Review 46 (3): 523-556.

- - - 2016. "Legal Mobilization under Neo-Corporatist Governance. Environmental NGOs before the Conseil d'Etat in France, 1975-2010," Journal of Law and Courts, 4 (1): 103-130.

Waldschmidt, A. 2009. "Disability Policy of the European Union: The Supranational Level," European Journal of Disability Research, 3: 8-23.

Zeman, F. K. 1983. "Legal Mobilization: The Neglected Role of the Law in the Political System," American Political Science Review, 77 (3): 690-703. 